\title{
LANDSLIDE SUSCEPTIBILITY ASSESSMENT USING OPEN-SOURCE DATA IN THE FAR WESTERN NEPAL HIMALAYA: CASE STUDIES FROM SELECTED LOCAL LEVEL UNITS
}

\author{
Kabi Raj Paudyal ${ }^{1}$, Krishna Chandra Devkota ${ }^{1,2, *}$, Binod Prasad Parajuli ${ }^{3}$, Puja Shakya ${ }^{3}$, Preshika Baskota ${ }^{3}$ \\ ${ }^{1}$ Central Department of Geology, Tribhuvan University, Kathmandu, Nepal \\ ${ }^{2}$ Global Institute for Interdisciplinary Studies, Kathmandu, Nepal \\ ${ }^{3}$ Practical Action Consulting South Asia, Kathmandu 44600, Nepal \\ *Corresponding author: engeokrishna@gmail.com \\ (Received: May 22, 2021; Revised: September 26, 2021; Accepted: October 01, 2021)
}

\begin{abstract}
This paper explores openly available geo-spatial and earth observatory data to understand landslide risk in data scarce rural areas of Nepal. It attempts to explore the application of open-source data and analytical models to inform future landslide research. The first step of this procedure starts from the review of global open datasets, literatures and case studies relevant to landslide research. The second step is followed by the case study in one of the mountainous municipalities of Nepal where we tested the identified open-source data and models to produce landslide susceptibility maps. Past studies and experiences show that the major potential sites of landslide in Nepal are highly concentrated in a geologically weak area such as the active fault regions, shear zones, axis of folds and unfavorable setting of lithology. Triggering factors like concentrated precipitation, frequent earthquake phenomenon and haphazard infrastructural development activities in the marginally stable mountain slopes have posed serious issues of landslides mostly through the geologically weak regions. In this context, openly available geo-spatial datasets can provide baseline information for exploring the landslide hazard scenario in the data scarce areas of Nepal. This research has used the available open-source data to produce a landslide susceptibility map of the Bithadchir Rural Municipality in Bajhang District and Budiganga Municipality in Bajura District of the Sudurpaschim Province of Nepal. We used qualitative analysis to evaluate the parameters and assess the susceptibility of landslide; the result was classified into five susceptibility zones: Very High, High, Moderate, Low, and Very Low. Slope and Aspect were identified to be the major determinants for the assessment. This approach is applicable, specifically, for the preliminary investigation in the data scarce region using open data sources. Furthermore, the result can be used to plan and prioritize effective disaster risk reduction strategies.
\end{abstract}

Keywords: Analytical model, landslide susceptibility, Nepal Himalaya, open-source data, pair-wise comparison

\section{INTRODUCTION}

Nepal lies in tectonically active zone, due to movement of Indian Plate towards Eurasian Plate that has resulted in frequent earthquake in the region (Chaulagain et al., 2015). This has triggered large number of landslides and weakened the slope that has decreased slope stability threshold (Dahlquist \& West, 2019). In addition to the seismic activity, land degradation was accelerated due to large intensity short duration rainfall, steep slopes, young and fragile geology, etc. (Devkota et al., 2013; Regmi et al., 2016; Nepal et al., 2019).

Disasters resulting from natural hazards in Nepal have been responsible for the high economic cost and social consequences, particularly for low income and vulnerable people. Landslides cause significant human loss including damage to the economy every year (Jelínek et al., 2007; Gallina et al., 2016). In Nepal, large number of landslides occur due to high monsoon precipitation (DHM, 2017). Furthermore, urbanization has exacerbated the scenario and increased landslide due to rapid human intervention that has destabilized the mountain slope by haphazard construction of non-engineered roads, improper watershed management, rapid expansion of the residential areas, etc. Specifically, after the 2015 Gorkha Earthquake, numerous landslide-hazard assessments have been conducted throughout the country by a number of government agencies, international experts, and national and international actors in Nepal (Regmi et al., 2016; Shrestha \& Kang, 2017; Xu et al., 2017; Gnyawali et al., 2019). The efforts were mainly focused on rapid visual-assessments aiming to find safer locations for temporary shelters to relocate earthquake-affected people and to identify the preliminary causes of earthquake-induced landslides in fragile mountainous areas. These activities helped to identify the existing landslide situation and possible future landslide scenario which alerts the relevant authorities to mainstream landslide risks for the resilient development in Nepal.

With increasing magnitudes and frequencies of landslide hazards in last 20 years $(2000-2019)$ (UNDRR/CRED, 2020), assessment of impact, scenarios, and mitigation and adaptation options for the disaster risk reduction is crucial 
for exposed vulnerable communities in mountainous countries like Nepal. High-resolution remote sensing technology is vital in an effective disaster risk reduction, however, the technology is limited and expensive to be adopted by developing countries for effective assessment and response to disaster (Malgwi et al., 2020). Therefore, identification and application of open-source geo-spatial data for the assessment of landslide susceptibility of the data-scarce remote area of Nepal is vital. Furthermore, understanding of disaster is critical, specifically, in developing countries with limited coping capacity (UNDRR, 2019).

Landslide study and mitigation efforts requires proper assessment and identification of high-risk areas from several aspects (Budha et al., 2016; Ambrosi et al., 2018; Jharendra et al., 2018; Timalsina \& Paudyal, 2018; Meena et al., 2021). Ghimire (2010) and Dahal et al. (2012) assessed the regional distribution pattern of the landslide hazard and evaluated the susceptible areas in Siwalik hills. After the 2015 Gorkha Earthquake, researchers (Collins \& Jibson, 2015; Roback et al., 2018) have explored and investigated the spatial distribution and its topographic characteristics of earthquake triggered landslides. Different approaches has been used to understand the landslides in Nepal, such as direct geomorphological mapping (Hearn, 1993; Weidinger et al., 1996), heuristic (Bijukchhen et al., 2012; Regmi et al., 2021) approaches, and data driven (Dahal et al., 2008; Kayastha et al., 2013a; Meena et al., 2019) approaches.
Landslide susceptibility is defined as the spatially-varying and time-independent likelihood of landslides occurrence in the area of interest (Brabb, 1985; Reichenbach et al., 2018; Psomiadis et al., 2020). Landslides susceptibility assessment (LSM) can be categorized into three basic methods: knowledge driven (expert opinion based), data driven (statistical analysis of historical landslides data) and physically based (numerical modelling of slope stability) (Corominas et al., 2014). For larger areas with large number of landslide occurrence, data driven methods of LSM are useful, and for detailed site-specific study, physically based methods are useful that employs high resolution geotechnical and hydrological (Mergili et al., 2014). In knowledge driven method, the landslide conditioning factors are identified by the experts, and each factor are ranked or scored qualitatively to identify the importance of individual factor on the occurrence of landslide (Kaur et al., 2018; Sur et al., 2021) and thus the success of this method is dependent on the expert knowledge (Westen et al., 2003; Sur et al., 2020). Although data driven models using machine learning and physically based models in GIS are popular, they have limited applicability in data scarce areas like remote locations of Nepal. Especially at locations which have complex geo-tectonic setting and small number of active landsides, a knowledge driven or heuristic method of LSM captures the complex non-linear relationship between landslide conditioning factors and landslide susceptibility (Ruff \& Czurda, 2008; Kaur et al., 2018).

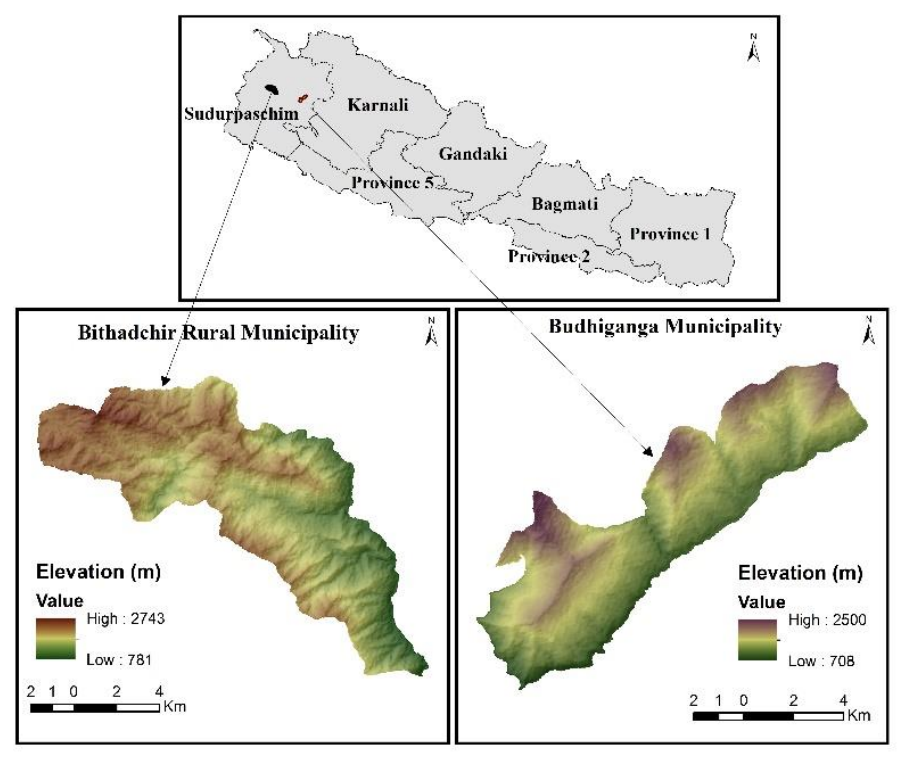

Figure 1. Location map of the study area

Nepal's geography is characterized by rugged mountains, remote and dispersed hilly settlements. Data on landslide locations is rarely recorded unless it causes a fatal event (Froude \& Petley, 2018), mainly because of limited funding.
Thus, event-based landslide inventory or high-resolution hydro-geological data is often unavailable in Nepal. The limited availability of data, especially in remote locations like western and far western districts of Nepal, makes it 
impossible to use the data driven or physically based methods for LSM. In such locations, heuristic knowledge driven method is thus suitable. In this paper, an attempt is made to review the available open-source information and employ it to assess landslide susceptibility in data scarce area, in the Bithadchir Rural Municipality of Bajhang District and Budiganga Municipality of Bajura -District of far western Nepal (Fig. 1). We applied the knowledge driven method of LSM using five landslide conditioning factors (slope, aspect, landuse, geology and drainage distance). We used freely available data, open-source software and analytical tools to understand the landslide hazard scenario, suitable for upscaling in resource limited countries like Nepal. The results will help in proper land use planning of rural municipalities on Nepal and provide input for policy formulation on hazard assessment and development planning.

\section{MATERIALS AND METHODS}

This study focuses on reviewing the available open-source information in the data scarce area of Nepal and explores the application in understanding the landslide risk in the area, to inform policy makers, land use planners and geohazard experts to plan and propose necessary mitigation measures, and development activities. Specifically, Bithadchir Rural Municipality of Bajhang District and Budiganga Municipality of Bajura District in the Sudurpaschim Province of Nepal (Fig. 1) is taken as a case study to provide a baseline information for exploring the landslide hazard scenario in the data scarce areas of Nepal.

\section{Available open-source data}

Open-source data and models are the freely available information and software, which are usually free from any mechanisms of control, specifically used for humanitarian proposes like disaster understanding, aid and rehabilitation. This study restricts itself to the open-source geo-spatial data and software (QGIS) to evaluate its importance in understanding landslide risk in the data scarce environment.

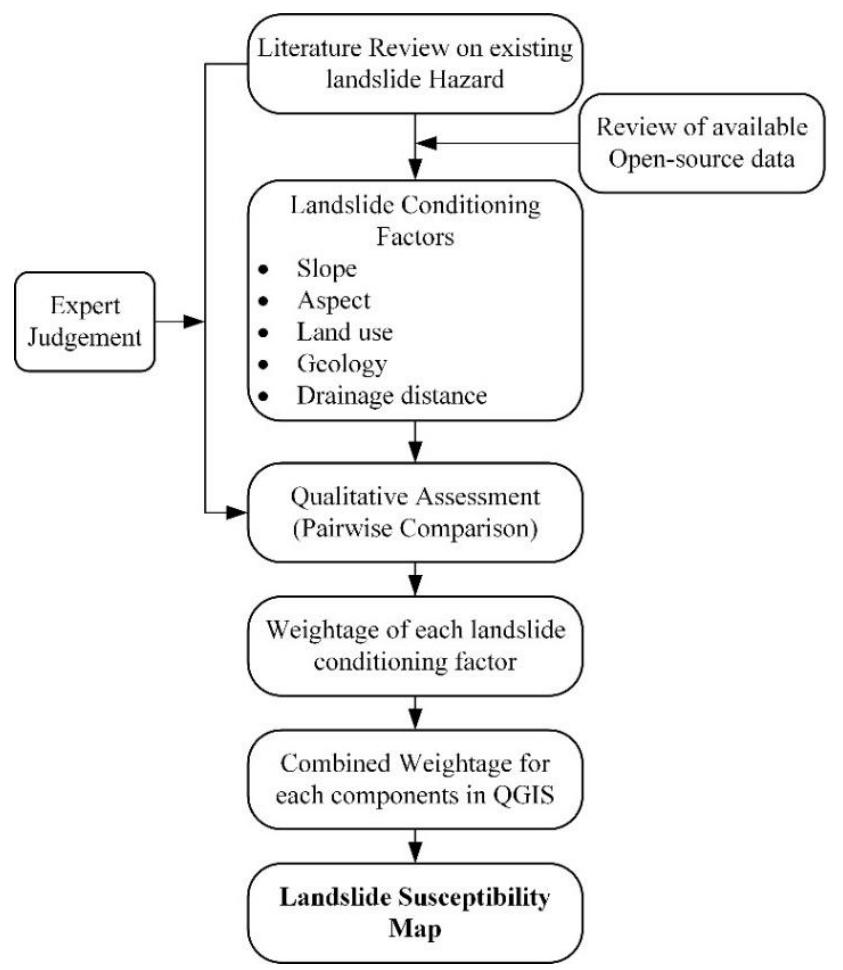

Figure 2. Methodological framework

The topographical information required for understanding the landslide mechanism can be acquired from the global datasets of USGS (United States Geological Survey) (https://earthexplorer.usgs.gov/). Landsat images of $30 \mathrm{~m}$ resolution available in USGS server can be used to classify the vegetation index and understand the land use pattern. However, in the context of Nepal, regional database system of International Centre for Integrated Mountain Development (https://rds.icimod.org/) has provided the readily available land use map of 2010 obtained from processing Landsat8 images. Furthermore, it also provides the database for the geological data for Nepal. Open street map (https://www.geofabrik.de/) can provide information regarding the road, drainage and buildings, and are regularly 
updated by humanitarian agencies and openly accessible to any user. These data and software used for this study are freely available and can be used and accessed by any registered user. However, other coarse resolution geospatial data are also available which is applicable in the national or regional context (of larger area). These data include but are not limited to soil and rock information (https://data.isric.org/), sentinel images to monitor and understand landslide movement (https://earthexplorer.usgs.gov/) and precipitation information from Tropical Rainfall Measuring Mission (https://climatedataguide.ucar.edu/climate-data/trmmtropical-rainfall-measuring-mission).

\section{Study area setting (Case Study)}

The Bithhadchir Rural Municipality has an area of 86 square kilometers and the Budhiganga Municipality has an area of 59 square kilometers. Elevation range in Bithadchir Rural Municipality varies from $781 \mathrm{~m}$ to $2743 \mathrm{~m}$, and elevation range in Budhiganga Municipality varies from 708 $\mathrm{m}$ to $2500 \mathrm{~m}$ (Fig. 1). This study was carried out according to the methodological framework presented in (Fig. 2), emphasizing the application of open-source data and analytical models in Nepal. Firstly, a comprehensive review on existing landslide hazard and susceptibility maps produced under similar geoclimatic settings was made. Then, landslide conditioning factors were identified, based on the expert judgement, field investigation, and review of various literature (Bhandary et al., 2013; Kayastha et al., 2013b). The spatial data of the landslide conditioning factors are collected through the open sources data. The open-source spatial datasets and their spatial resolution used in this study are presented in Table 1. The opensource GIS software - QGIS was used to compile, manipulate and prepare each thematic map and produce the final susceptibility map. Qualitative assessment of the landslide conditioning factor based on the expert judgement, is carried out to rank and quantify the relative importance of a landslide conditioning factor. Finally, the combined weightage from the direct and indirect approaches were integrated in the GIS environment. We categorized the landslide susceptibility map into five susceptibility zones based on quantile classification, in order to evaluate the landslide susceptibility of the region.

Table 1. Open-source spatial dataset used in the study

\begin{tabular}{llll}
\hline S.N. & Data & Source & Scale/Spatial Resolution \\
\hline $\mathbf{1}$ & DEM & SRTM DEM (earthexplorer.usgs.gov) & $30 \mathrm{~m}$ \\
$\mathbf{2}$ & Drainage & $\begin{array}{l}\text { Open Street Map } \\
\text { (https://www.geofabrik.de/) }\end{array}$ & NA \\
$\mathbf{3}$ & Landcover and land use & ICIMOD (2013) & $30 \mathrm{~m}$ \\
$\mathbf{4}$ & Geology (Lithology) & ICIMOD (2007) & $1: 1,000,000$ \\
\hline
\end{tabular}

\section{Landslide conditioning factors}

The basic landslide conditioning factors used in this study were slope, aspect, distance from stream, geology, and land use type. Shuttle Radar Topography Mission (SRTM) is a higher resolution $(\sim 30 \mathrm{~m})$ digital elevation model (DEM) that is available freely with a decent consistency and accuracy. The SRTM DEM is processed further to derive other topographical landslide conditioning factors in QGIS i.e., slope and aspect.

Slope represents the steepness of the terrain and is an important factor for landslide occurrence. Landslide usually occurs in a steep slope (Saha et al., 2010) because shear stress is increased with steepness (Dai \& Lee, 2001; Acharya et al., 2016) that reduces the stability of slope and causes failure. Slope (in degree) is categorized into four classes: 020, 20-40, 40-60, and 60-90 (Fig. 3).

Aspect (slope direction) is generated from the SRTM DEM in QGIS. Aspect plays an important role in vegetation growth (Bobrowsky, 2008; Pourghasemi et al., 2013), precipitation pattern, discontinuities orientation, etc. (Devkota et al., 2011), that ultimately affects the stability of the slope. Based on the direction of slope, it is classified in nine classes: Flat, North, Northeast, East, Southeast, South, Southwest, West, Northwest, and North (Fig. 4).

Land use change disturbs the slope inclination, causes the disturbance in the slope materials, and affects the flow of the water causing the decrease in slope stability (Neaupane \& Piantanakulchai, 2006; Hamza \& Raghuvanshi, 2017). Accordingly, land use is categorized into six classes: Agricultural area, Forest, Shrubland, Barren Area, Grassland, and Water Body (Fig. 5).

Streams usually makes a slope susceptible to failure by either cutting the slope or eroding the slope materials. Moreover, it increases the saturation of the materials reducing the frictional strength (Mersha \& Meten, 2020). Distance from stream is categorized into six categories for the assessment (Fig. 6). 


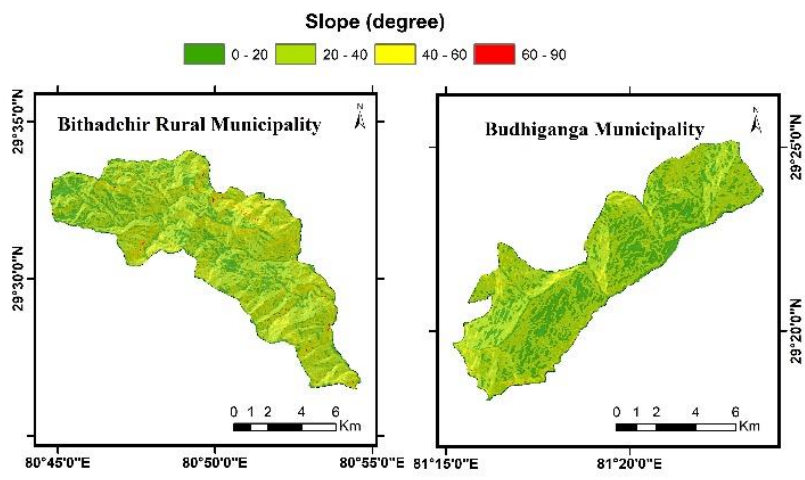

Figure 3. Slope map of the study area

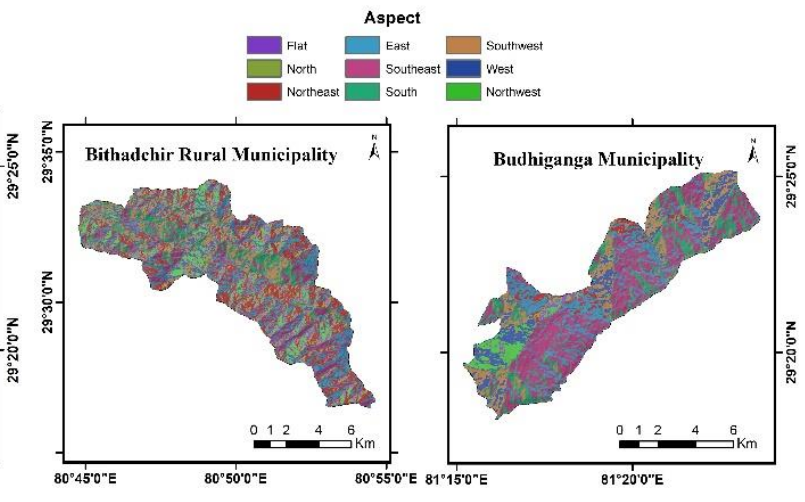

Figure 4. Aspect map of the study area

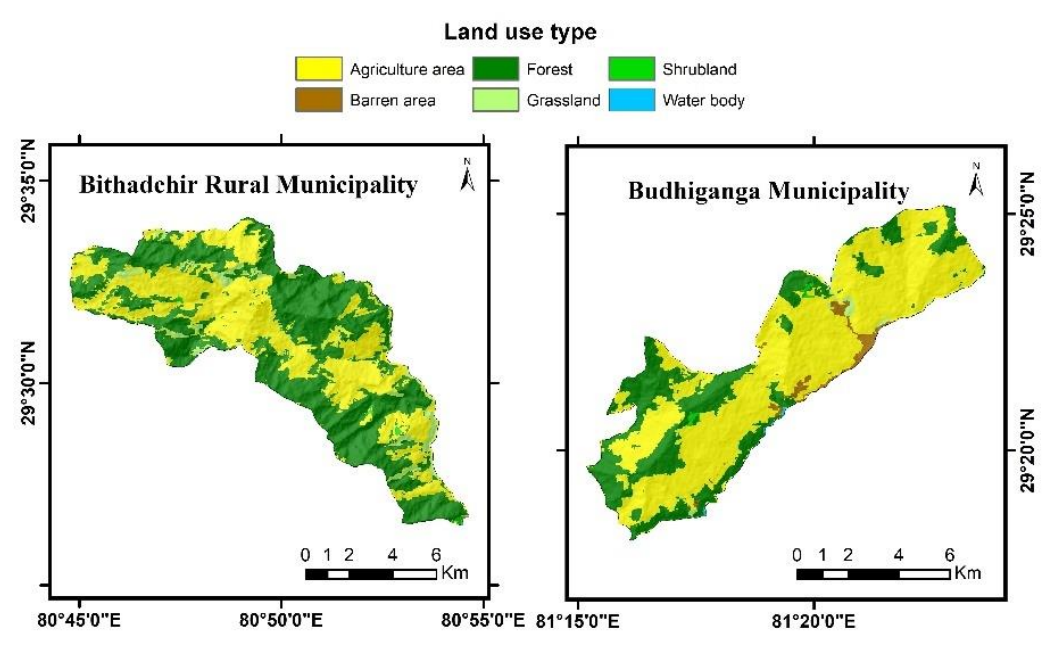

Figure 5. Land use map of the study area

Geological factor represents the lithology of the area collected from openly available regional database system of ICIMOD (https://rds.icimod.org/). It identifies the relative strengths of the material, weathering and ground water conditions, etc. (Nepal et al., 2019), that can assess whether the precondition of the area is susceptible to landslides or not. Geology is categorized into six classes: Basic Rocks, Galyang Formation, Ranimatta Formation, $\mathrm{Bu}$, Lakharpata Formation and Sallyani Gad Formation (Fig. 7).

\section{Qualitative assessment of landslide susceptibility}

In this study, two methods of LSM from knowledge driven approach are applied and compared - direct and indirect methods. In indirect method, pair-wise comparison matrix is used to derive the weight of each landslide conditioning factor. However, in the direct approach, expert judgement was utilized to assess weight of subclasses in each landslide conditioning factor (Devkota et al., 2011). Finally, the total susceptibility score is calculated, which is the sum of the product of the weight of each parameter and subsequent weights of subclasses. For this analysis, the landslide susceptibility can be calculated based on equation (1).

$L S=\sum_{i=1}^{n} \sum_{j=1}^{m} W_{i} W_{i j}$

Where,

LS = Landslide Susceptibility

$W_{i}=$ Weight of the landslide conditioning factor from

pair-wise comparison

$W_{i j}=$ Weight of subclasses of landslide conditioning factor 


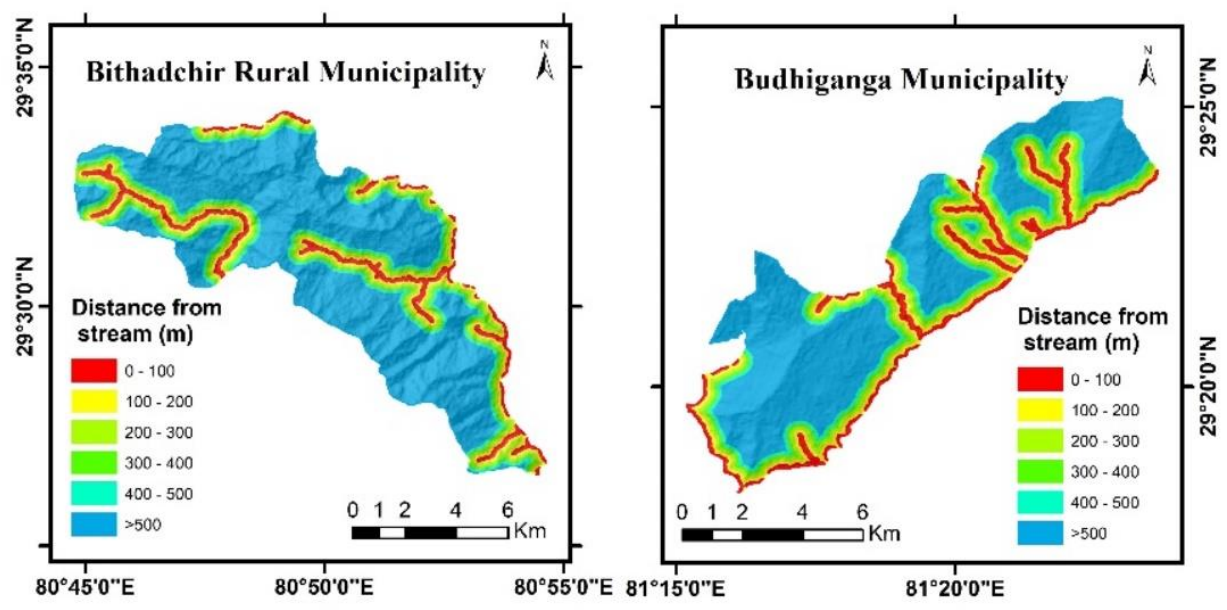

Figure 6. Distance from drainage map of the study area

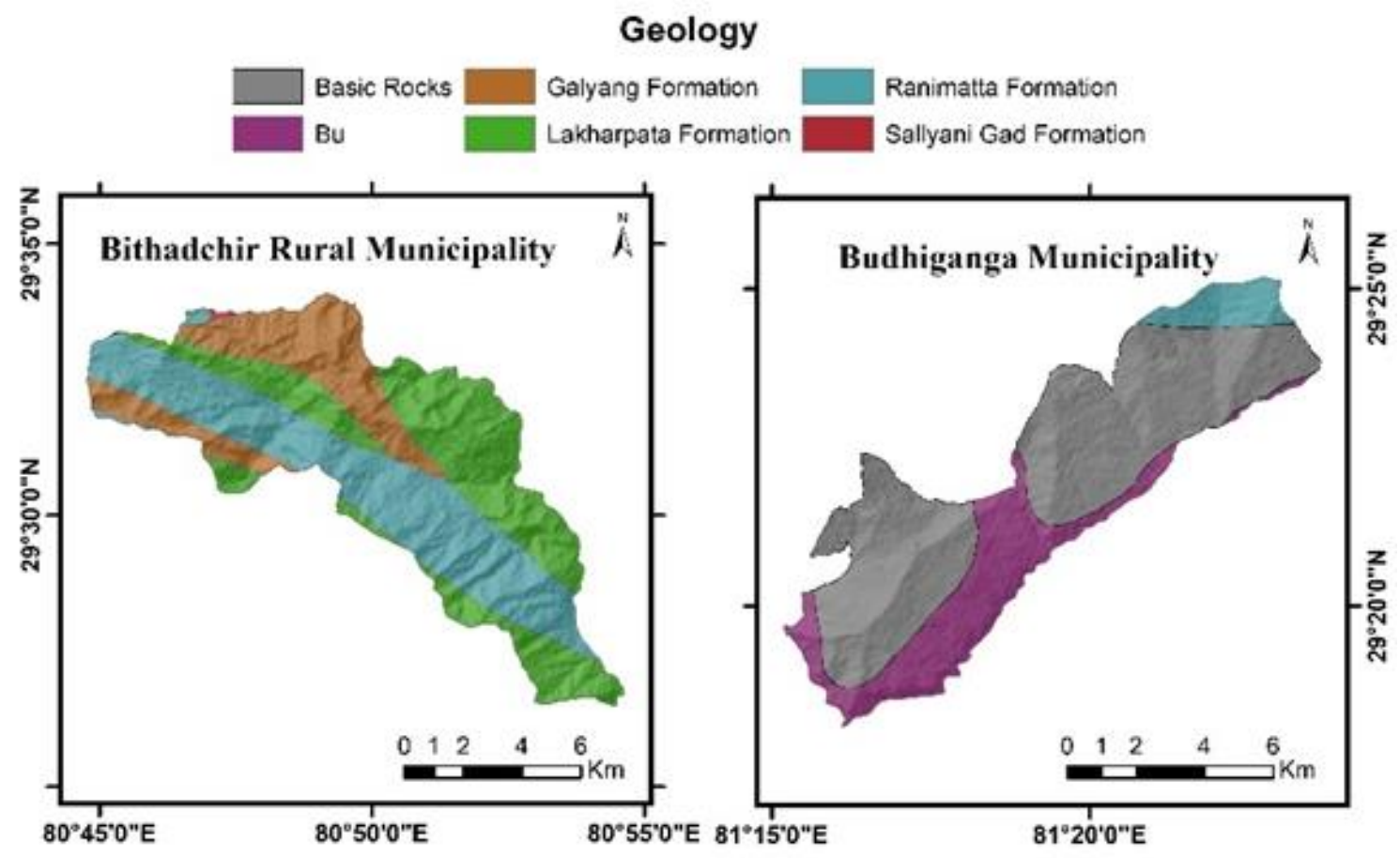

Figure 7. Geological map of the study area (ICIMOD, 2007)

We used pairwise comparison to identify the relative importance of each landslide conditioning factor in a scale from 1 to 7. The pair-wise comparison matrix used in the indirect method is presented in Table 2. Pairwise weights of each landslide conditioning factor are input by expert judgement.

In the direct approach, expert judgement based on the site scenario and literature review is employed to assess the weightage of each sub-class of the landslide conditioning factor presented in Table 3. The sub-classes were classified qualitatively in accordance to the presence and absence of landslides, and literature review. Each of the sub-classes were given weightage by the expert to quantify the importance of each sub-classes within a landslide condition factor. For this study, in direct approach, expert gave weight of each sub-classes between 1 and 4, where the higher weightage represents the higher susceptibility to landslides and vice versa. 
Table 2. Weightage of landslide conditioning factor using pair-wise comparison.

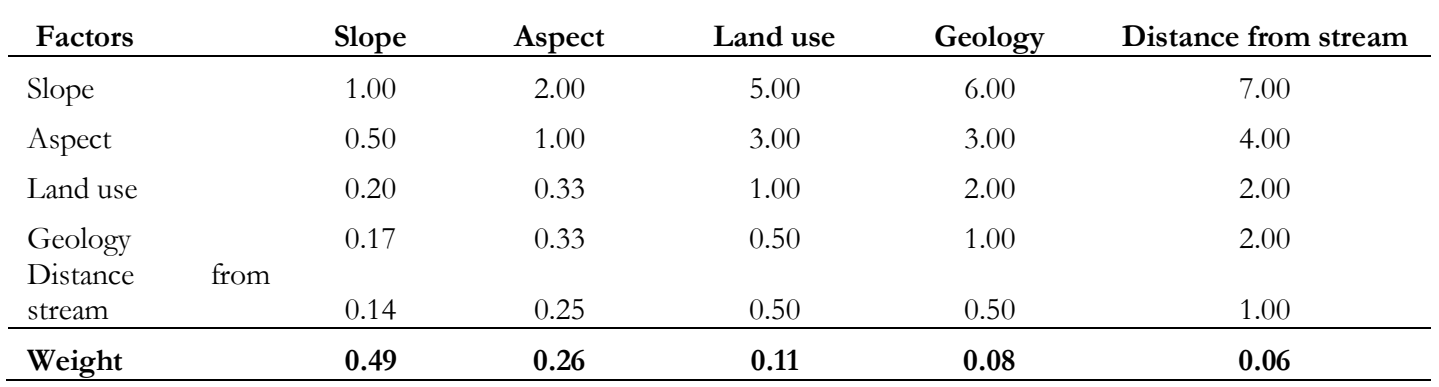

Table 3. Weightage of each sub-class of landslide conditioning factor using expert opinion.

\begin{tabular}{|c|c|c|}
\hline Factors & Classification & Weight \\
\hline \multirow{4}{*}{ Slope Inclination (degree) } & $0-20$ & 1 \\
\hline & $20-40$ & 4 \\
\hline & $40-60$ & 3 \\
\hline & $60-90$ & 1 \\
\hline \multirow{9}{*}{ Slope Direction (Aspect) } & Flat & 1 \\
\hline & $\mathrm{N}$ & 2 \\
\hline & $\mathrm{NE}$ & 1 \\
\hline & $\mathrm{E}$ & 2 \\
\hline & SE & 2 \\
\hline & S & 3 \\
\hline & SW & 3 \\
\hline & W & 2 \\
\hline & NW & 2 \\
\hline \multirow{6}{*}{ Distance from stream (m) } & $0-100$ & 4 \\
\hline & $100-200$ & 4 \\
\hline & $200-300$ & 2 \\
\hline & $300-400$ & 2 \\
\hline & $400-500$ & 1 \\
\hline & $>500$ & 1 \\
\hline \multirow{6}{*}{ Land-use type } & Agriculture Area & 2 \\
\hline & Barren Land & 4 \\
\hline & Forest & 4 \\
\hline & Grassland & 2 \\
\hline & Shrubland & 2 \\
\hline & Water body & 1 \\
\hline \multirow{6}{*}{ Geology } & Basic Rock & 1 \\
\hline & $\mathrm{Bu}$ & 1 \\
\hline & Galyang Formation & 1 \\
\hline & Lakharpata Formation & 2 \\
\hline & Ranimatta Formation & 3 \\
\hline & Salyani Gad Formation & 2 \\
\hline
\end{tabular}

Table 4. Percentage of Area in each susceptibility zones.

\begin{tabular}{ccc}
\hline Susceptibility Zones & $\begin{array}{c}\text { Percent of Area } \\
\text { (Bithadchir Rural Municipality) }\end{array}$ & $\begin{array}{c}\text { Percent of Area } \\
\text { (Budhiganga Municipality) }\end{array}$ \\
\hline Very Low & 20.71 & 29.79 \\
Low & 5.68 & 2.10 \\
Moderate & 24.75 & 23.37 \\
High & 33.64 & 32.29 \\
Very High & 15.22 & 12.44 \\
\hline
\end{tabular}




\section{RESULTS AND DISCUSSION}

The final evaluation score was assessed applying the weightage depicted in Table 2 and Table 3 on equation (1). The final evaluation score was classified by quantile classification to divide into five susceptibility zones: Very Low, Low, Moderate, High, and Very High; this classification is represented in Fig. 8. Forty eight percent of the area in Bithadchir rural municipality and 44 percent of area in Budhiganga municipality lie in high and very high landslides susceptibility region, Table 4.

Identification of the area susceptible to landslide hazards can recognize the area that requires an immediate intervention. The disaster risk reduction and mitigation activities can be prioritized in these areas, and detailed site investigation of the sites of major importance can be conducted. The result can be fruitful in the sustainable planning and implementation of development works (Corominas et al., 2014). It can help development planner and policy makers to grasp the accurate situation in the region to effectively allocate resources to cope with the issue. Although limited open-source data was available, this research effectively investigated and utilized available opensource geo-spatial information to assess the susceptibility of the area. The data sources and assessment strategy of this study can be applied in similar regional assessments. This result can serve as a baseline study for a preliminary feasibility assessment of development activities. Application of open source data plays an important role to understand disaster in data-scarce region, and evaluate the progress in the achievement of global targets of Sendai Framework for Disaster Risk Reduction (Li et al., 2019).

Designed with an aim of understanding the availability of open-source data in the context of Nepal, and utilizing the information in the practical context for rapid and easy method of landslides susceptibility assessment for remote areas of Nepal, our approach has some limitations as well. Firstly, we used square pixels as mapping units in this study. Slope units provide a geomorphological segmentation of the terrain between drainage and divide lines (Alvioli et al., 2016), and the code for this is also open-source and available freely. Secondly, limited number of landslide conditioning factors have been used in this study, so other factors such as rainfall, soil type, soil thickness, etc. which are openly available in relatively coarse resolution can be included in future analysis to improve the prediction rate for regional assessment. In McAdoo et al. (2018) investigated landslides distribution in the Sindhupalchowk district in central Nepal and found that the likelihood of landslide occurrence nearby poorly engineered roads is two-fold than on terrain without roads. Other data like rainfall, soil depth, and soil type can also be acquired using satellite based remote sensing but these need a calibration using ground observations, thus hindering the rapid and easy approach of LSM applicable in rural areas of Nepal. Advanced data driven machine learning techniques like artificial neural networks, random forest, gradient boosting, etc. can be applied in future research (Reichenbach et al., 2018; Merghadi et al., 2020). However, in context of limited data on past occurrence of landslides, like that in our case, these models have to be firstly tested and optimized, and this process also needs an input from the heuristic approach for calibration. The knowledge driven approach is expert dependent and cannot guarantee the reproduction of same results when different experts investigate the same study area (Ruff \& Czurda, 2008; Kaur et al., 2018).

Landslide occurrences in Nepal are a function of the inherently weak geology and physiography of slopes, combined with triggers such as heavy monsoon rainfall, cloudburst, and earthquakes. These factors vary in different physiographic, geologic, and climatic zones. Landslides understanding can be improved through the accurate analysis of preconditions including physiographic conditions, climatic zones, and geologic scenario of an area that affects the terrain (Upreti, 2001). The potential sites for landslides are found at and adjacent to the adverse geological structures like active faults and brittle shear zones (Timalsina \& Paudyal, 2018), axis of tight folds, abundant shear zones and deep weathering. Furthermore, evaluation of the geological, geomorphological, and hydrological situations that led to past landslides can provide valuable insights and information to precisely predict the occurrence of the future failures. Therefore, the data of rainfall and geological maps are the utmost important for landslide hazard and ultimately the risk evaluation. However, both of these data and maps are not openly available online. The Department of Hydrology and Meteorology (DHM) provides the data of rainfall. Similarly, geological map of Nepal and data of seismicity can be brought from the Department of Mines and Geology (DMG). Some of such maps and data are available from the Tribhuvan University Central Library (TUCL) and related departments of Hydrology and Metrology and Geology. One has to pay for such data and maps to release from the government agencies. Therefore, this information can be rated as semi-open or can be rated in easily available but not openly available group. Similarly, aerial photographs are commonly used to map existing landslides, detect the locations of potential landslides, and identify the surface expressions of present and historical landslides. Although aerial imageries can also be an effective tool to detect change and identify landslides in the area, it requires complex techniques and experience to evaluate accurately (Yagi, 2011). Furthermore, in the context of Nepal Himalaya, aerial photos are not found as open access. Department of Survey of Government of Nepal provides such aerial photos with certain cost. In these regards, landslide risk assessment based on the openly available sources is challenging. In this situation, preparation of landslide susceptibility mapping can only be the most suitable technique for landslide sensitivity assessment and its risks. 


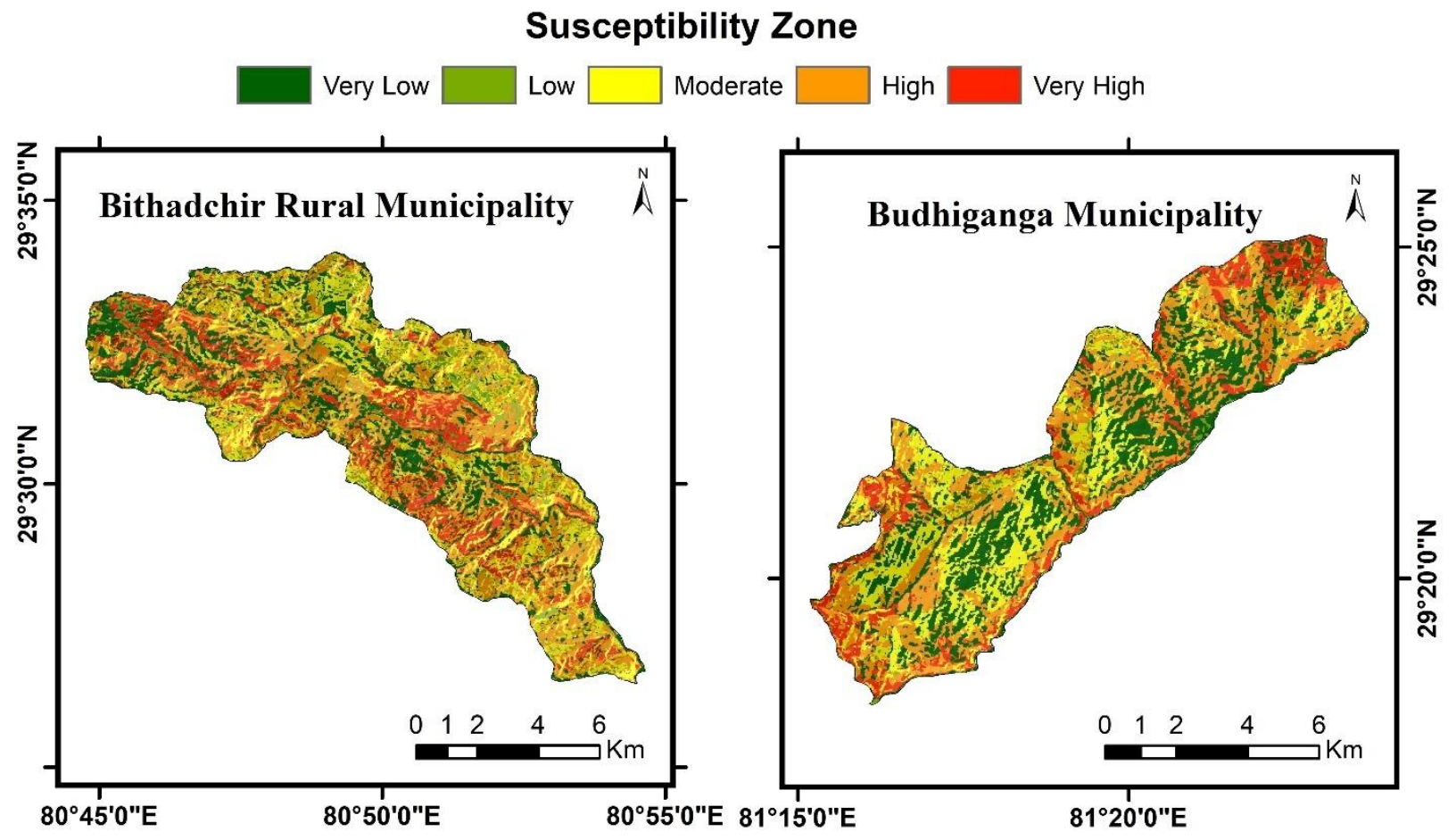

Figure 8. Landslide susceptibility map of the study area.

Table 5. Validation of landslide susceptibility map.

\begin{tabular}{|c|c|c|c|}
\hline \multirow{2}{*}{ Municipality } & \multicolumn{2}{|c|}{ Landslide Location } & \multirow{2}{*}{ Susceptibility Zone } \\
\hline & Longitude & Latitude & \\
\hline \multirow{10}{*}{$\begin{array}{l}\text { Bithadchir Rural } \\
\text { Municipality }\end{array}$} & $80^{\circ} 47^{\prime} 44.88^{\prime \prime}$ & $29^{\circ} 32^{\prime} 5.64^{\prime \prime}$ & Very High \\
\hline & $80^{\circ} 47^{\prime} 42.36^{\prime \prime}$ & $29^{\circ} 32^{\prime} 5.64^{\prime \prime}$ & Very High \\
\hline & $80^{\circ} 48^{\prime} 3.96^{\prime \prime}$ & $29^{\circ} 32^{\prime} 0.6^{\prime \prime}$ & High \\
\hline & $80^{\circ} 49^{\prime} 7.32^{\prime \prime}$ & $29^{\circ} 32^{\prime} 2.04^{\prime \prime}$ & High \\
\hline & $80^{\circ} 46^{\prime} 39.36^{\prime \prime}$ & $29^{\circ} 31^{\prime} 37.56^{\prime \prime}$ & High \\
\hline & $80^{\circ} 46^{\prime} 37.56^{\prime \prime}$ & $29^{\circ} 31^{\prime} 36.12^{\prime \prime}$ & High \\
\hline & $80^{\circ} 46^{\prime} 40.08^{\prime \prime}$ & $29^{\circ} 31^{\prime} 37.2^{\prime \prime}$ & High \\
\hline & $80^{\circ} 49^{\prime} 46.56^{\prime \prime}$ & $29^{\circ} 30^{\prime} 12.6^{\prime \prime}$ & High \\
\hline & $80^{\circ} 49^{\prime} 17.4^{\prime \prime}$ & $29^{\circ} 31^{\prime} 41.52^{\prime \prime}$ & High \\
\hline & $80^{\circ} 53^{\prime} 14.64^{\prime \prime}$ & $29^{\circ} 26^{\prime} 58.2^{\prime \prime}$ & High \\
\hline \multirow{10}{*}{$\begin{array}{l}\text { Budhiganga } \\
\text { Municipality }\end{array}$} & $81^{\circ} 20^{\prime} 37.32^{\prime \prime}$ & $29^{\circ} 24^{\prime} 16.2^{\prime \prime}$ & Moderate \\
\hline & $81^{\circ} 23^{\prime} 26.16^{\prime \prime}$ & $29^{\circ} 23^{\prime} 42.72^{\prime \prime}$ & Very High \\
\hline & $81^{\circ} 19^{\prime \prime} 32.52^{\prime \prime}$ & $29^{\circ} 23^{\prime} 42^{\prime \prime}$ & Low \\
\hline & $81^{\circ} 20^{\prime \prime} 24.36^{\prime \prime}$ & $29^{\circ} 22^{\prime} 57^{\prime \prime}$ & High \\
\hline & $81^{\circ} 16^{\prime} 35.76^{\prime \prime}$ & $29^{\circ} 21^{\prime} 11.88^{\prime \prime}$ & Very High \\
\hline & $81^{\circ} 20^{\prime} 51.72^{\prime \prime}$ & $29^{\circ} 23^{\prime} 11.76^{\prime \prime}$ & High \\
\hline & $81^{\circ} 21^{\prime} 34.92^{\prime \prime}$ & $29^{\circ} 22^{\prime} 50.88^{\prime \prime}$ & Very High \\
\hline & $81^{\circ} 21^{\prime} 18^{\prime \prime}$ & $29^{\circ} 22^{\prime} 38.28^{\prime \prime}$ & High \\
\hline & $81^{\circ} 22^{\prime} 37.2^{\prime \prime}$ & $29^{\circ} 23^{\prime} 17.88^{\prime \prime}$ & Very High \\
\hline & $81^{\circ} 15^{\prime} 27^{\prime \prime}$ & $29^{\circ} 19^{\prime} 27.48^{\prime \prime}$ & Very High \\
\hline
\end{tabular}

Validation of landslide susceptibility map

Landslide inventory of Bithadchir rural municipality and Budhiganga municipality is prepared digitizing 10 landslide points each using the multi-temporal Google Earth images. Using the spatial analysis in QGIS, the susceptibility zones of each point is analyzed (Table 5). The results depicts that most of the landslide points lies on the very high and high susceptible zones, presenting the accuracy of the prepared susceptibility map. However, the precise estimation of the slope stability requires a deterministic approach using the physical parameters. 


\section{CONCLUSIONS}

This study has used the available open-source data for landslide sensitivity and risk assessment in the data scarce remote region of Nepal Himalaya. An attempt is made to evaluate susceptibility of the landslide using open-source analytical tools as a preliminary information of landslide hazard evaluation. The present review paper assumes that the preparation of susceptibility mapping using open and semi-open data is a way to assess the risk. It assesses the landslide susceptibility of the Bithhadchir Rural Municipality (Bajhang District) and Budiganga Municipality (Bajura District) of the Sudurpaschim Province as a case study. Remote areas of Nepal often lack data about the past landslide occurrences, so we assessed landslide susceptibility using expert knowledge and limited data in a free and open-source environment. We employed expert judgment to quantify the complex relationship between the causative factors to cause a landslide event; the combined final score for an area was categorized into five susceptibility zones: Very Low, Low, Moderate, High, and Very High. Slope and aspect were identified to be the major determinants for the assessment. The results can be used as baseline information for the detailed site investigation, and planning phase of the development scheme. Moreover, this research also uses the available open-source geo-spatial data, reports, research papers available online which can also be used for the future researches in other wider region of Nepal Himalaya where there is sparse database of landslides.

\section{ACKNOWLEDGEMENTS}

The initial draft manuscript was supported by the Data Innovation Fund program led by the World Bank's Development Economics Data Group and funded by the Trust Fund for Statistical Capacity Building III. Authors are greateful towards the Practical Action Family and Mr. Kaushal Gyawali, Mr. Nirdesh Nepal and Mr. Jharendra K.C. for their valuable contributions during the manuscript preparation.

\section{AUTHOR CONTRIBUTIONS}

KRP and KCD have equal contribution for data collection, data analysis and interpretation and final manuscript preparation. BPP, PS and PB have the role for manuscript review, data analysis, figure preparation and financial collaboration to carry out this research.

\section{CONFLICT OF INTEREST}

The authors declare no competing interests.

\section{DATA AVAILABILITY STATEMENT}

The data that support the findings of this study are available from the corresponding author, upon reasonable request.

\section{REFERENCES}

Acharya, T.D., Mainali, S.C., Yang, I.T., \& Lee, D.H. (2016). Analysis of Jure Landslide dam, Sindhupalchowk Using GIS and Remote Sensing. ISPRS - International Archives of the Photogrammetry, Remote Sensing and Spatial Information Sciences, XLI-B6, 201-203.

Alvioli, M., Marchesini, I., Reichenbach, P., Rossi, M., Ardizzone, F., Fiorucci, F., \& Guzzetti, F. (2016). Automatic delineation of geomorphological slope units with r. slopeunits v1. 0 and their optimization for landslide susceptibility modeling. Geoscientific Model Development, 9(11), 3975-3991.

Ambrosi, C., Strozzi, T., Scapozza, C., \& Wegmüller, U. (2018). Landslide hazard assessment in the Himalayas (Nepal and Bhutan) based on Earth-Observation data. Engineering Geology, 237, 217-228. doi:10.1016/j.enggeo.2018.02.020.

Bhandary, N.P., Yatabe, R., Dahal, R.K., Hasegawa, S., \& Inagaki, H. (2013). Areal distribution of large-scale landslides along highway corridors in central Nepal. Georisk: Assessment and Management of Risk. for Engineered Systems and Geohazards, 7(1), 120. doi:10.1080/17499518.2012.743377.

Bijukchhen, S.M., Kayastha, P., \& Dhital, M.R. (2012). A comparative evaluation of heuristic and bivariate statistical modelling for landslide susceptibility mappings in GhurmiDhad Khola, east Nepal. Arabian Journal of Geosciences, 6(8), 2727-2743. doi:10.1007/s12517-012-0569-7.

Bobrowsky, P.T. (2008). Landslides processes, prediction and land use, American Geographical Union, water resources monograph 18, Roy C. Sidle and Hirotaka Ochiai (2006). Landslides, 5(2), 241-241. doi:10.1007/s10346-008-0119-2.

Brabb, E.E. (1985). Innovative approaches to landslide hazard and risk mapping. Paper presented at the International Landslide Symposium Proceedings, Toronto, Canada.

Budha, P.B., Paudyal, K., \& Ghimire, M. (2016). Landslide susceptibility mapping in eastern hills of Rara Lake, western Nepal. Journal of Nepal Geological Society, 50(1), 125-131.

Chaulagain, H., Rodrigues, H., Silva, V., Spacone, E., \& Varum, H. (2015). Seismic risk assessment and hazard mapping in Nepal. Natural Hazards, 78(1), 583-602. doi:10.1007/s11069015-1734-6.

Collins, B.D., \& Jibson, R.W. (2015). Assessment of existing and potential landslide hazards resulting from the April 25, 2015 Gorkha, Nepal earthquake sequence (2015-1142), Reston, VA. Retrieved April 25, 2020 from http://pubs.er.usgs.gov/ publication/ofr20151142.

Corominas, J., van Westen, C., Frattini, P., Cascini, L., Malet, J.P., Fotopoulou, S., Catani, F., Van Den Eeckhaut, M., Mavrouli, O., Agliardi, F., Pitilakis, K., Winter, M.G., Pastor, M., Ferlisi, S., Tofani, V., Hervás, J., \& Smith, J.T. (2014). Recommendations for the quantitative analysis of landslide risk. Bulletin of Engineering Geology and the Environment, 73(2), 209-263.

Dahal, R.K., Hasegawa, S., Bhandary, N.P., Poudel, P.P., Nonomura, A., \& Yatabe, R. (2012). A replication of landslide hazard mapping at catchment scale. Geomatics, Natural Hazards and Risk, 3(2), 161-192. doi:10.1080/19475705.2011.629007.

Dahal, R.K., Hasegawa, S., Nonomura, A., Yamanaka, M., Dhakal, S., \& Paudyal, P. (2008). Predictive modelling of rainfall-induced landslide hazard in the Lesser Himalaya of Nepal based on weights-of-evidence. Geomorphology, 102(3-4), 496-510.

Dahlquist, M.P., \& West, A.J. (2019). Initiation and runout of post-seismic debris flows: Insights from the 2015 Gorkha earthquake. Geophysical Research Letters, 46(16), 9658-9668. doi:10.1029/2019g1083548.

Dai, F.C., \& Lee, C.F. (2001). Terrain-based mapping of landslide susceptibility using a geographical information system: a case 
study. Canadian Geotechnical Journal, 38(5), 911-923. doi:10.1139/t01-021.

Devkota, K.C., Park, D.K., Kim, T.H., \& Oh, J.R. (2011). GIS based Landslide Susceptibility Prediction for Mt. Umyeon, Seoul. Paper presented at the Proceedings of KSEG 2011 Fall Conference, November 10-11, 2011.

Devkota, K.C., Regmi, A.D., Pourghasemi, H.R., Yoshida, K., Pradhan, B., Ryu, I.C., Dhital, M.R., \& Althuwaynee, O.F. (2013). Landslide susceptibility mapping using certainty factor, index of entropy and logistic regression models in GIS and their comparison at Mugling-Narayanghat road section in Nepal Himalaya. Natural Hazards, 65(1), 135-165. doi:10.1007/s11069-012-0347-6.

DHM. (2017). Observed Climate Trend Analysis in the Districts and Physiographic Regions of Nepal (1971-2014). Kathmandu: Department of Hydrology and Meteorology.

Froude, M.J., \& Petley, D.N. (2018). Global fatal landslide occurrence from 2004 to 2016. Natural Hazards and Earth System Sciences, 18(8), 2161-2181.

Gallina, V., Torresan, S., Critto, A., Sperotto, A., Glade, T., \& Marcomini, A. (2016). A review of multi-risk methodologies for natural hazards: Consequences and challenges for a climate change impact assessment. Journal of Environmental Management, 168,123-132. doi:10.1016/j.jenvman.2015.11.011

Ghimire, M. (2010). Landslide occurrence and its relation with terrain factors in the Siwalik Hills, Nepal: case study of susceptibility assessment in three basins. Natural Hazards, 56(1), 299-320. doi:10.1007/s11069-010-9569-7.

Gnyawali, K.R., Zhang, Y., Wang, G., Miao, L., Pradhan, A.M. S., Adhikari, B.R., \& Xiao, L. (2019). Mapping the susceptibility of rainfall and earthquake triggered landslides along ChinaNepal highways. Bulletin of Engineering Geology and the Environment, 79, 587-601. doi:10.1007/s10064-019-01583-2.

Hamza, T., \& Raghuvanshi, T.K. (2017). GIS based landslide hazard evaluation and zonation - A case from Jeldu District, Central Ethiopia. Journal of King Saud University - Science, 29(2), 151-165. doi:10.1016/j.jksus.2016.05.002.

Hearn, G.J. (1993). Rapid geomorphological reconnaissance survey for road alignment in West Nepal. Bulletin of the International Association of Engineering Geology - Bulletin de l'Association Internationale de Géologie de l'Ingénieur, 48(1), 59-68. doi:10.1007/bf02594976.

ICIMOD. (2007). Geology of Nepal. Kathmandu, Nepal: ICIMOD.

ICIMOD. (2013). Land cover of Nepal 2010. Kathmandu, Nepal: ICIMOD.

Jelínek, R., Hervás, J., \& Wood, M. (2007). Risk Mapping of Landslides in New Member States. Unisdr Org.

Jharendra, K., Gautam, D., Neupane, P., \& Paudyal, K.R. (2018). Landslide inventory mapping and assessment along the Ramche-Jharlang area in Dhading, Rasuwa and Nuwakot districts, Lesser Himalaya Central Nepal. Journal of Nepal Geological Society, 55(1), 103-108.

Kaur, H., Gupta, S., Parkash, S., \& Thapa, R. (2018). Knowledgedriven method: a tool for landslide susceptibility zonation (LSZ). Geology, Ecology, and Landscapes, 1-15.

Kayastha, P., Dhital, M.R., \& De Smedt, F. (2013a). Application of the analytical hierarchy process (AHP) for landslide susceptibility mapping: A case study from the Tinau watershed, west Nepal. Computers \& Geosciences, 52, 398-408. doi:10.1016/j.cageo.2012.11.003.

Kayastha, P., Dhital, M.R., \& Smedt, F.D. (2013b). Evaluation of the consistency of landslide susceptibility mapping: a case study from the Kankai watershed in east Nepal. Landslides, 10(6), 785-799. doi:10.1007/s10346-012-0361-5.
Li, G., Zhao, J., Murray, V., Song, C., \& Zhang, L. (2019). Gap analysis on open data interconnectivity for disaster risk research. Geo-spatial Information Science, 22(1), 45-58. doi:10.1080/10095020.2018.1560056.

Malgwi, M.B., Fuchs, S., \& Keiler, M. (2020). A generic physical vulnerability model for floods: review and concept for datascarce regions. Natural Hazards and Earth System Sciences, 20(7), 2067-2090. doi:10.5194/nhess-20-2067-2020.

McAdoo, B.G., Quak, M., Gnyawali, K.R., Adhikari, B.R., Devkota, S., Rajbhandari, P.L., \& Sudmeier-Rieux, K. (2018). Roads and landslides in Nepal: how development affects environmental risk. Natural Hazards and Earth System Sciences, 18(12), 3203-3210. doi:10.5194/nhess-18-3203-2018.

Meena, S., Ghorbanzadeh, O., \& Blaschke, T. (2019). A Comparative Study of Statistics-Based Landslide Susceptibility Models: A Case Study of the Region Affected by the Gorkha Earthquake in Nepal. ISPRS International Journal of Geo-Information, 8(2), 94. doi:10.3390/ijgi8020094.

Meena, S.R., Albrecht, F., Hölbling, D., Ghorbanzadeh, O., \& Blaschke, T. (2021). Nepalese landslide information system (NELIS): a conceptual framework for a web-based geographical information system for enhanced landslide risk management in Nepal. Natural Hazards and Earth System Sciences, 21(1), 301-316. doi:10.5194/nhess-21-301-2021.

Merghadi, A., Yunus, A.P., Dou, J., Whiteley, J., ThaiPham, B., Bui, D.T., Avtar, R., \& Abderrahmane, B. (2020). Machine learning methods for landslide susceptibility studies: A comparative overview of algorithm performance. Earth-Science Reviews, 207, 103225. doi:https://doi.org/10.1016/j.earscirev .2020 .103225 .

Mergili, M., Marchesini, I., Alvioli, M., Metz, M., SchneiderMuntau, B., Rossi, M., \& Guzzetti, F. (2014). A strategy for GIS-based 3-D slope stability modelling over large areas. Geoscientific Model Development, 7(6), 2969-2982.

Mersha, T., \& Meten, M. (2020). GIS-based landslide susceptibility mapping and assessment using bivariate statistical methods in Simada area, northwestern Ethiopia. Geoenvironmental Disasters, 7(1), 20. doi:10.1186/s40677-02000155-x.

Neaupane, K.M., \& Piantanakulchai, M. (2006). Analytic network process model for landslide hazard zonation. Engineering Geology, 85(3-4), 281-294. doi:10.1016/j.enggeo.2006.02.003.

Nepal, N., Chen, J., Chen, H., Wang, X.A., \& Pangali Sharma, T.P. (2019). Assessment of landslide susceptibility along the Araniko Highway in Poiqu/Bhote Koshi/Sun Koshi Watershed, Nepal Himalaya. Progress in Disaster Science, 3, 100037. doi:10.1016/j.pdisas.2019.100037.

Pourghasemi, H.R., Moradi, H.R., Fatemi Aghda, S.M., Gokceoglu, C., \& Pradhan, B. (2013). GIS-based landslide susceptibility mapping with probabilistic likelihood ratio and spatial multi-criteria evaluation models (North of Tehran, Iran). Arabian Journal of Geosciences, 7(5), 1857-1878. doi:10.1007/s12517-012-0825-x.

Psomiadis, E., Papazachariou, A., Soulis, K., Alexiou, D.-S., \& Charalampopoulos, I. (2020). Landslide Mapping and Susceptibility Assessment Using Geospatial Analysis and Earth Observation Data. Land, 9(5), 133. doi: $10.3390 /$ land 9050133 .

Regmi, A.D., Dhital, M.R., Zhang, J.-Q., Su, L.-J., \& Chen, X.-Q. (2016). Landslide susceptibility assessment of the region affected by the 25 April 2015 Gorkha earthquake of Nepal. Journal of Mountain Science, 13(11), 1941-1957. doi:10.1007/s11629-015-3688-2. 
Regmi, N.R., Giardino, J.R., Vitek, J.D., \& Dangol, V. (2010). Mapping Landslide Hazards in Western Nepal: Comparing Qualitative and Quantitative Approaches. Environmental \& Engineering Geoscience, 16(2), 127-142. doi:10.2113/gseegeosci .16.2.127.

Reichenbach, P., Rossi, M., Malamud, B.D., Mihir, M., \& Guzzetti, F. (2018). A review of statistically-based landslide susceptibility models. Earth-Science Reviens, 180, 60-91.

Roback, K., Clark, M.K., West, A.J., Zekkos, D., Li, G., Gallen, S.F., Chamlagain, D., \& Godt, J.W. (2018). The size, distribution, and mobility of landslides caused by the 2015 $\mathrm{M}(\mathrm{w}) 7.8$ Gorkha earthquake, Nepal. Geomorphology, 301, 121138. doi:10.1016/j.geomorph.2017.01.030.

Ruff, M., \& Czurda, K. (2008). Landslide susceptibility analysis with a heuristic approach in the Eastern Alps (Vorarlberg, Austria). Geomorphology, 94(3-4), 314-324.

Saha, A.K., Gupta, R.P., \& Arora, M.K. (2010). GIS-based Landslide Hazard Zonation in the Bhagirathi (Ganga) Valley, Himalayas. International Journal of Remote Sensing, 23(2), 357-369. doi:10.1080/01431160010014260.

Shrestha, S., \& Kang, T.-S. (2017). Assessment of seismicallyinduced landslide susceptibility after the 2015 Gorkha earthquake, Nepal. Bulletin of Engineering Geology and the Environment, 78(3), 1829-1842. doi:10.1007/s10064-017-11914.

Sur, U., Singh, P., \& Meena, S.R. (2020). Landslide susceptibility assessment in a lesser Himalayan road corridor (India) applying fuzzy AHP technique and earth-observation data. Geomatics, Natural Hazards and Risk, 11(1), 2176-2209. doi:10.1080/19475705.2020.1836038.

Sur, U., Singh, P., Rai, P.K., \& Thakur, J.K. (2021). Landslide probability mapping by considering fuzzy numerical risk factor (FNRF) and landscape change for road corridor of Uttarakhand, India. Environment Development and Sustainability, 23(9), 13526-13554. doi:10.1007/s10668-021-01226-1.
Timalsina, K., \& Paudyal, K.R. (2018). Fault-controlled geomorphic features in Ridi-Shantipur area of Gulmi District and their implications for active tectonics. Journal of Nepal Geological Society, 55(1), 157-165.

UNDRR. (2019). Disaster Risk Reduction in Nepal: Status Report 2019. Asian Disaster Preparedness Center, UN Office for Disaster Risk Reduction, Bangkok, Thailand.

UNDRR/CRED. (2020). The buman cost of disasters: an overview of the last 20 years (2000-2019). Geneva, Switzerland: United Nations Office for Disaster Risk Reduction (UNDRR)/Centre for Research on the Epidemiology of Disasters(CRED).

Upreti, B. (2001). The physiography and geology of Nepal and landslide hazards. Landslide problem mitigation to the HindukushHimalayas, ICIMOD, 312.

Weidinger, J.T., Schramm, J.M., \& Surenian, R. (1996). On preparatory causal factors, initiating the prehistoric Tsergo $\mathrm{Ri}$ landslide (Langthang Himal, Nepal). Tectonophysics, 260(1-3), 95-107. doi:10.1016/0040-1951(96)00078-9.

Westen, C.V., Rengers, N., \& Soeters, R. (2003). Use of geomorphological information in indirect landslide susceptibility assessment. Natural Hazards, 30(3), 399-419.

Xu, C., Tian, Y., Zhou, B., Ran, H., \& Lyu, G. (2017). Landslide damage along Araniko highway and Pasang Lhamu highway and regional assessment of landslide hazard related to the Gorkha, Nepal earthquake of 25 April 2015. Geoenvironmental Disasters, 4(1). doi:10.1186/s40677-017-0078-9.

Yagi, H. (2001). Landslide study using aerial photographs. Landslide hazard mitigation in the Hindu Kush-Himalayas. ICIMOD, Nepal.

Internet sources

https://climatedataguide.ucar.edu/climate-data/trmm-tropicalrainfall-measuring-mission

https://data.isric.org/

https:/ / earthexplorer.usgs.gov/

https://rds.icimod.org/

https://www.geofabrik.de/ 